\title{
Longitudinally extensive transverse myelitis and meningitis due to a rare infectious cause
}

\author{
Diana Moreira Amaral, ${ }_{1}^{1}$ Tiago Parreira, ${ }^{2}$ Mafalda Sampaio ${ }^{3}$
}

${ }^{1}$ Hospital Pediátrico Integrado - Centro Hospitalar São João, Porto, Portugal

${ }^{2}$ Serviço de Neurorradiologia, Centro Hospitalar de São João, Porto, Portugal

${ }^{3}$ Unidade de Neuropediatria, Hospital Pediátrico Integrado - Centro Hospitalar São João, Porto, Portugal

\section{Correspondence to} Dr Diana Moreira Amaral, jooniper@hotmail.com

Accepted 8 July 2015
CrossMark

\section{To cite: Amaral DM}

Parreira T, Sampaio M. BMJ Case Rep Published online: [please include Day Month Year] doi:10.1136/bcr-2015211761

\section{DESCRIPTION}

A previously healthy 9-year-old girl was admitted to the emergency department of a district hospital due to persistent headache for 3 days. Somnolence, fever and meningismus were noticed. No previous infections or recent immunisations were reported. The child had leucocytosis with elevated $\mathrm{C}$ reactive protein. Cerebrospinal fluid (CSF) analysis showed pleocytosis of 96 cells, $73 \%$ of lymphocytes, with negative bacteriological, enterovirus and herpes simplex virus screen. Ceftriaxone was started. Owing to persistent fever and headache, a brain CT

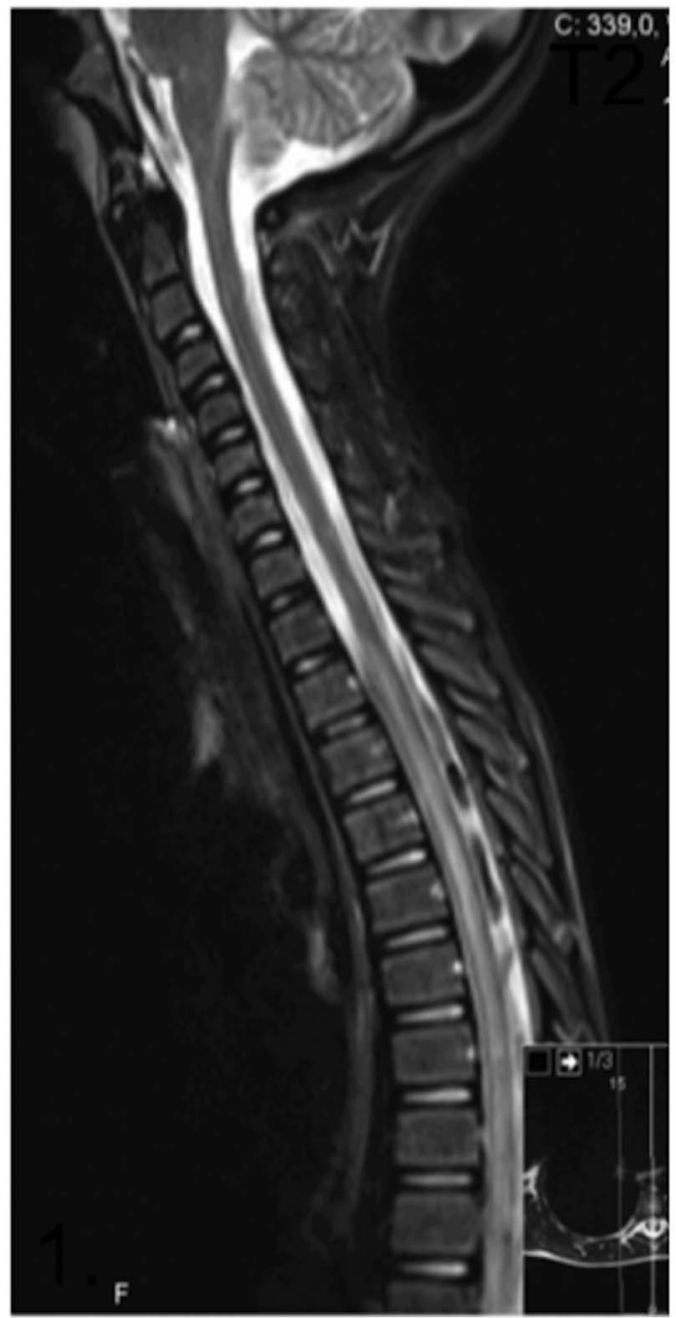

Figure 1 Spinal cord MRI, sagittal T2-weighted images showing a hyperintense lesion on T2-weighted sequence, centrally located, occupying more than two-thirds of the cross-sectional area and leading to spinal cord expansion, extending from D2 to D10. There was no significant enhancement with gadolinium. scan was performed, showing no abnormalities. Focal and generalised seizures started by the ninth day of disease, followed by right-sided Todd hemiparesis. A second lumbar puncture showed increased pleocytosis (316 cells, 66\% of lymphocytes). Acyclovir and vancomycin were added and the patient was transferred to our hospital with the diagnostic hypothesis of meningoencephalitis. On admission, she presented a normal level of consciousness, and the physical examination showed flaccid paraparesis, pain and vibratory hypoesthesia below T2 and bilateral cervical adenopathy. Ciprofloxacin was added. Brain MRI revealed leptomeningeal enhancement with no basal ganglia or thalami involvement. Spinal cord MRI showed a longitudinally extensive transverse myelitis (figures 1 and 2). Neoplastic and autoimmune causes were ruled out, including negative neuromyelitis optica IgG (NMO-IgG). The extensive microbiological screening revealed positivity for Epstein-Barr virus (EBV) DNA in blood $\left(6.5 \times 10^{3}\right.$ copies of EBV $\mathrm{DNA} / \mathrm{mL}$ ) and in CSF (900 copies of EBV DNA/ $\mathrm{mL}$ ), with positive early EBV IgG and borderline EBV IgM. Treatment included a 5-day course of immunoglobulin and 28-day course of endovenous ganciclovir followed by oral valganciclovir. The patient gradually improved, regaining ability to walk, though maintaining a neurogenic bladder and left foot drop.

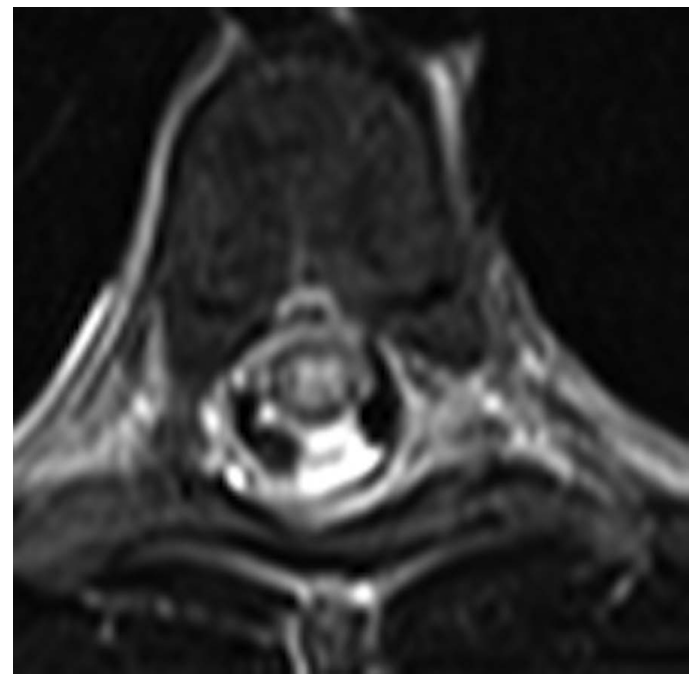

Figure 2 Spinal cord MRI, axial T2-weighted images showing a hyperintense lesion on T2-weighted sequence, centrally located, occupying more than two-thirds of the cross-sectional area and leading to spinal cord expansion, extending from D2 to D10. There was no significant enhancement with gadolinium. 


\section{Learning points}

In this patient, the association of fever and meningismus with elevated inflammatory markers, made the diagnosis of infectious myelopathy and meningitis very likely. However, the extensiveness of the lesion (more than three vertebral segments) imposed the exclusion of other inflammatory causes, such as neuromyelitis optica (NMO)-spectrum disorders. ${ }^{1}$ Although a negative NMO-IgG does not exclude this diagnosis, the finding of positivity for EBV in blood as well as in cerebrospinal fluid, and the apparent response to the antiviral and immunomodulating therapy, support the diagnosis of an infectious myelopathy. ${ }^{1}$

- Transverse myelitis is a rare complication of Epstein-Barr virus (EBV) infection, or postinfectious state, usually with poor prognosis. ${ }^{2}$

- Treatment of EBV-induced transverse myelitis remains controversial, since evidence-based results are not available. $^{2} 3$
Contributors All the authors contributed substantially to the conception of the work, and to the analysis and interpretation of the clinical and imaging data. They also contributed to drafting of the work, which was mainly performed by DMA; TP and MS revised it critically for important intellectual content. All the authors approve the version sent for publishing and agree to be accountable for all aspects of the work.

Competing interests None declared.

Patient consent Obtained.

Provenance and peer review Not commissioned; externally peer reviewed.

\section{REFERENCES}

1 Wingerchuk DM. Infectious and inflammatory myelopathies. CONTINUUM Lifelong Learn Neurol 2008;14:36-57.

2 Maiid A, Galetta SL, Sweeney CJ, et al. Epstein-Barr virus myeloradiculitis and encephalomyeloradiculitis. Brain 2002;125:159-65.

3 Bouguila J, Tej $A$, Hasni I, et al. Epstein-Barr virus infection and acute transverse myelitis. Med Mal Infect 2012;42:83-4.

Copyright 2015 BMJ Publishing Group. All rights reserved. For permission to reuse any of this content visit

http://group.bmj.com/group/rights-licensing/permissions.

BMJ Case Report Fellows may re-use this article for personal use and teaching without any further permission.

Become a Fellow of BMJ Case Reports today and you can:

- Submit as many cases as you like

- Enjoy fast sympathetic peer review and rapid publication of accepted articles

- Access all the published articles

- Re-use any of the published material for personal use and teaching without further permission

For information on Institutional Fellowships contact consortiasales@bmjgroup.com

Visit casereports.bmj.com for more articles like this and to become a Fellow 